Indonesian Journal of Medicine (2017), 3(2): 184-191

https://doi.org/10.26911/theijmed.2017.02.03.06

\title{
Survival Predictors of People Living with HIV/ AIDS in Wamena, Papua
}

\author{
Tena Kogoya'), Argyo Demartoto²), Bhisma Murti1) \\ 1)Masters Program in Public Health, Universitas Sebelas Maret \\ 2)Faculty of Social and Political Sciences, Universitas Sebelas Maret
}

\begin{abstract}
Background: Quality of life (QoL) is an important component in the evaluation of the well-being of people living with HIV and AIDS (PLWHA), especially with the appreciable rise in longevity of PLWHA. The analysis of the quality of life is essential for the healthcare policies and services directed toward PLWHA, since this indicator values the perception of people about their own life and health. However, little is known about the determinant of QoL in PLWHA in Papua. The aim of this study was to analyze survival predictors of people living with HIV/ AIDS in Wamena, Papua, Indonesia.

Subjects and Method: This was a retrospective cohort study conducted in Wamena Hospital, Papua, from December 2017 to February 2018. A cohort of 304 PLWHA was selected for this study from the medical record at Wamena Hospital. The dependent variable was survival. The independent variables were adherence to ART, nutritional status, age, and coinfection. The data were collected from medical record and questionnaire. The data were analyzed by Cox regression model.

Results: The risk of dying of PLWHA if adherent to take the ART was lower than not adherent to take the ART $(\mathrm{HR}=0.45 ; 95 \% \mathrm{CI}=0.06$ to $0.33 ; \mathrm{p}=0.002)$. The risk of dying of PLWHA with poor nutritional status was higher than good nutritional status $(\mathrm{HR}=12.78 ; 95 \% \mathrm{CI}=6.81$ to $23.98 ; \mathrm{p}<$ $0.001)$. The risk of dying of PLWHA aged $\geq 35$ years was slightly higher than $<35$ years $(\mathrm{HR}=1.47$; $95 \% \mathrm{CI}=1.00$ to $2.17 ; \mathrm{p}=0.050)$. The risk of dying of PLWHA with coinfected was higher than without coinfected $(\mathrm{HR}=1.59 ; 95 \% \mathrm{CI}=1.15$ to $2.23 ; \mathrm{p}=0.006)$.

Conclusion: The risk of dying of PLWHA decreases if adherent to take the ART, but increases with poor nutritional status, age $\geq 35$ years, and coinfection.
\end{abstract}

Keywords: survival, adherence to treatment, people living with HIV/ AIDS.

\section{Correspondence:}

Tena Kogoya. Masters Program in Public Health, Universitas Sebelas Maret, Jl. Ir. Sutami No. 36 A, 57126, Surakarta, Central Java. Email: tena.kogoya76@gmail.com. Phone: +628198869665.

\section{BACKGROUND}

Epidemiology of AIDS in Indonesia has lasted 20 years and the impact is not easy to overcome. According to the Indonesia Ministry of Health, the total number of HIV cases since 2005-2016 was 208,920 cases, in 2016 the total cases reached 17,847. while AIDS cases accounted for 11,807 cases. (Kemenkes RI, 2016).

The provincial government of Papua has reported a total of 22,429 HIV cases and 13,335 AIDS cases from 2005 to 2016 with 1,570 new cases. (Kemenkes RI, 2016)
Wamena District Hospital has reported the cumulative number of people who have been admitted to HIV treatment until April 2017 as many as 5304 people where only 730 people are screened for tuberculosis coinfection and 582 people are infected with TB. In addition, 388 people died until the end of April 2017.

There is no cure for HIV infection that has been found until now and there is no vaccine available for prevention, the infected person should take antiretroviral therapy for life, but this drug only can slow the progress- 
ion of the virus in the early stages. Even if they can survive, people living with HIV/ AIDS (PLWHA) may not live well or feel satisfied. Quality of life becomes important to identify the condition of PLWHA in living its life. (Hasanah et al., 2011; Arjun et al., 2015).

HIV/AIDS prevention program in Indonesia leading to the paradigm of zero new infection, zero AIDS-related death, and zero discrimination. These Paradigm were trying to be realized in four pillars, namely (1) Prevention of HIV transmission. (2) Care, support, and treatment (PDP). (3) Mitigation of impacts of psychosocial-economic support.

(4) Creation of a conducive environment.

The second pillar of Care, Support, and Treatment (CST) efforts include strengthening and developing health services, preventing and treating opportunistic infections, antiretroviral treatment, support education, and training for PLW.

The program aims to reduce morbidity and hospitalization rates, AIDS-related mortality rates, and improve the quality of life of HIV-infected persons at various stages. (Kementerian Kesehatan Republik Indonesia - Direktorat Jenderal Pengendalian Penyakit dan Penyehatan Lingkungan, 2011).

The aim of this study was to analyze survival predictors of people living with HIV/ AIDS in Wamena, Papua, Indonesia.

\section{SUBJECTS AND METHOD}

This was a retrospective cohort study conducted in Wamena Hospital, Papua, from December 2017 to February 2018.

A cohort of 304 PLWHA was selected for this study from the medical record at

Table 1. The results cox regression analysis of survival predictor of PLWHA

\begin{tabular}{llllr}
\hline \multirow{2}{*}{ Independent Variables } & \multirow{2}{*}{ HR } & \multicolumn{2}{c}{$\mathbf{9 5 \%}$ CI } & \multirow{2}{*}{ p } \\
\cline { 3 - 4 } & & Lower limit & Upper limit & \\
\hline Adherent to take the ART & 0.45 & 0.06 & 0.33 & 0.002 \\
Poor nutritional status & 12.78 & 6.81 & 23.98 & $<0.001$ \\
Aged $\geq 35$ years & 1.47 & 1.00 & 2.17 & 0.050 \\
Coinfected & 1.59 & 1.15 & 2.23 & 0.006 \\
N observation $=184$ & & & & \\
Log likelihood $=-84.53$ & & & & \\
p $<$ 0.001 & & & \\
\hline
\end{tabular}

Wamena Hospital. The dependent variable was survival. The independent variables were adherence to ART, nutritional status, age, and coinfection.

Survival was defined as the length of time required by the patient since the diagnosis of PLWHA to death.

Survival assessment for surviving patients is the length of the patient suffering from AIDS until the study is completed with a permanent status of life.

Co-infection is a coexisting disease experienced after a patient has AIDS, in other words, is a disease that arises as a result of AIDS include tuberculosis, sexually transmitted diseases, non-sexual infectious diseases, diarrhea, and other chronic diseases

The data were collected from medical record and questionnaire. The data were analyzed by Cox regression model.

\section{RESULTS}

The risk of dying of PLWHA if adherent to take the ART was lower than not adherent to take the ART $(\mathrm{HR}=0.45 ; 95 \% \mathrm{CI}=0.06$ to $0.33 ; p=0.002$ ).

The risk of dying of PLWHA with poor nutritional status was higher than good nutritional status $(\mathrm{HR}=12.78 ; 95 \% \mathrm{CI}=6.81$ to 23.98 ; $\mathrm{p}<0.001$ ).

The risk of dying of PLWHA aged $\geq 35$ years was slightly higher than $<35$ years $(\mathrm{HR}=1.47 ; 95 \% \mathrm{CI}=1.00$ to $2.17 ; \mathrm{p}=0.050)$. The risk of dying of PLWHA with coinfected was higher than without coinfected ( $\mathrm{HR}=$ 1.59; $95 \% \mathrm{CI}=1.15$ to $2.23 ; \mathrm{p}=0.006$ ). 

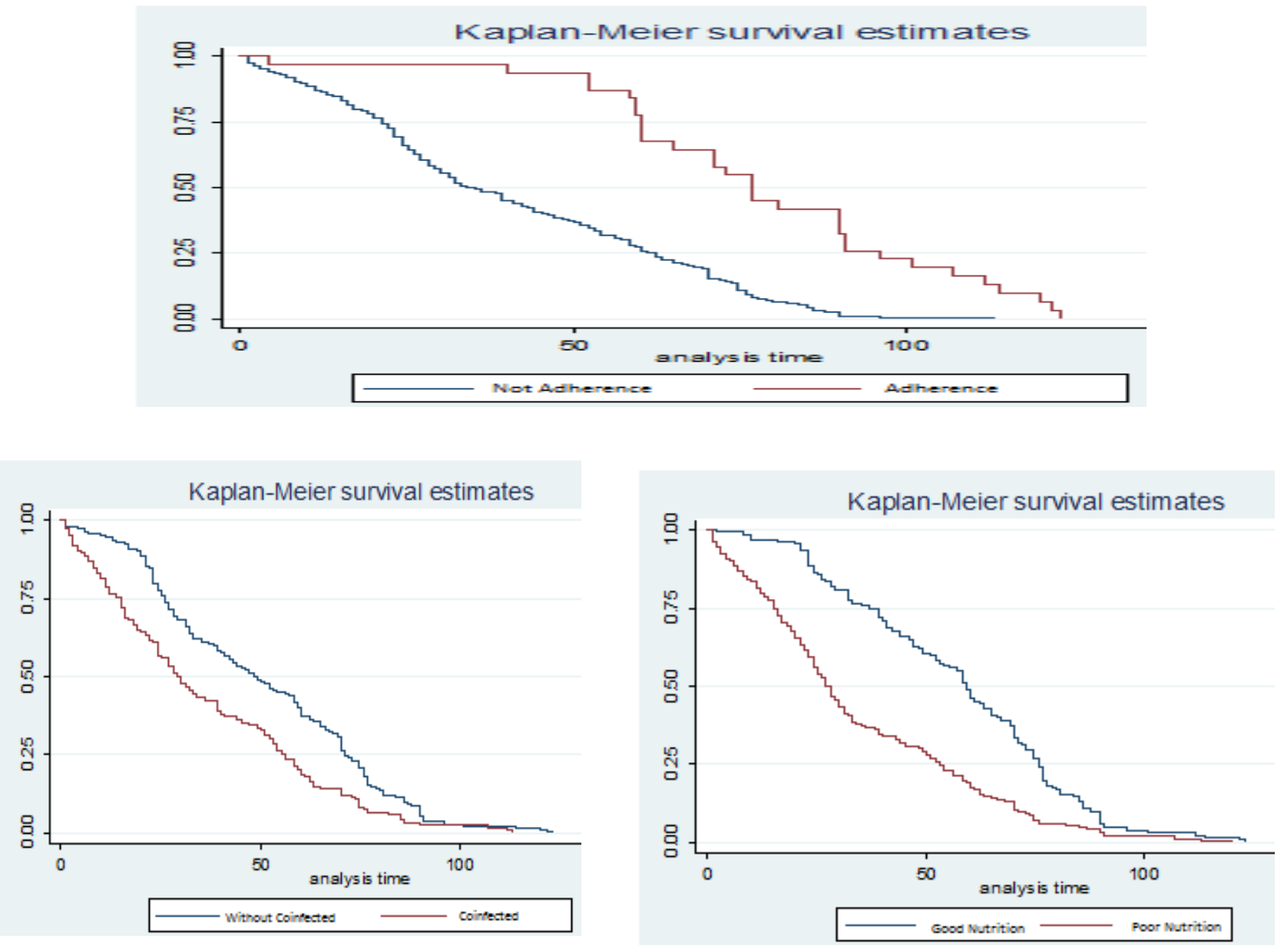

Figure 1. Kaplan-Meier Survival estimates

\section{DISCUSSIONS}

\section{Adherent to ART}

The development of antiretroviral drugs has significantly altered the perception of HIV / AIDS from a very potentially fatal illness to be chronic and potentially treatable, and the availability the administration of antiretroviral therapy (ART) has significantly reduced HIV and AIDS-related mortality and morbidity. (Oguntibeju, 2012)

This situation makes the World Health Organization (WHO) strive to achieve the 90\% coverage target of care for all HIV patients as well as $90 \%$ virological success in treated patients and requires a minimum achievement of adherence appro- ximately 95\% (UNAIDS,2015; Paterson et al., 2000).

According to(Iacob and Jugulete, 2017) here are 4 main factors that can affect ART adherence: (1) Selective antiretroviral drugs, which can cause various side effects. (2) Doctors' devotions include lack of time dedicated to counseling and building trust relationships. (3) Patients have not been able to receive the benefits and disadvantages of ART. (4) social and family backgrounds can not persuade patients to continue ART.

Effective antiretroviral therapy can decrease morbidity and mortality for people with a CD4 cell count of 200-350 cells / $\mathrm{mm} 3$. Various data indicate that decreased risk of mortality and complication related 
AIDS or non-AIDS in PLWHA who started ART when CD4 cell counts, 350 cells / $\mu \mathrm{L}$. (Schey., et al 2016).

In 2010, HIV-1 treatment guidelines in the United States and the EU recommended three fully active antiretroviral drugs when $\mathrm{CD} 4+$ cell in peripheral blood decreased to 350 cells / mm3, a stage where viral rates could often reach $10,000-$ 100,000 copies per mL.. (Arts and Hazuda, 2012; Lodi et al., 2011)

The Kaplan-Meier survival estimated of patients who adherent to antiretroviral therapy is much higher than non-adherent patients.

ART provides an effective treatment for patients with 6 classes of pharmacological drugs including: (1) Nucleoside reverse transcriptase inhibitors (NRTIs). (2) Non-nucleoside reverse transcriptase inhibitors (NNRTIs). (3) Protease inhibitors (PIs). (4) Integrase inhibitor (INSTIs). (5) Fusion Inhibitor (FI). (6) Chemokine receptor antagonist (CCR5 antagonist). (7) Inhibitor entry (post-mounted inhibitor directed to CD4). (Rathbun, 2017).

Each class targets different steps in the viral life cycle and its use in clinical practice was largely determined by ease or complexity of use, side effects, clinical efficacy, practice guidance, and physician preferences. Non-compliance causes a failure of therapy and the occurrence of resistance mechanisms.

NRTIs were managed as prodrugs requiring host cell entry and phosphorylation by cellular kinase before providing antiviral effects. NRTIs prevent the formation of 30-50-phosphodiester bonds resulting in termination of growth and termination of viral DNA chains. (Boyer et al., 2001; Rigourd et al., 2002).

Resistance to NRTIs was mediated by two mechanisms: ATP-dependent pyrophosphorolysis which is the removal of
NRTIs from the 30 ends of the newborn chains and increased discrimination between the deoxyribonucleotide substrate and the inhibitor. (Naeger., et al 2002).

NNRTI inhibits HIV-1 by binding and promoting the formation of proximal hydrophobic pockets. NNRTI binding to the virus may reduce polymerase activity. (Sluis-Cremer., et al 2004).

NNRTI resistance was generated from substitutions of amino acids such as L100, K101, K103, E138, V179, Y181, and Y188 in NNRTI binding sacs.. (Bacheler et al., 2000; Dykes et al., 2001).

The HIV-1 Protease is an enzyme responsible for the cleavage of viral gags and polyprotein precursor gags during virion maturation. However, protease genes have great plasticity, with polymorphism observed in 49 of 99 codons, and many more than 20 substitutions known to be associated with resistance (Shafer et al., 2007).

The HIV-1 entry exploits some host proteins for a set of complicated events leading to the fusion membrane and the release of the viral nucleus into the cytoplasm. Fusion Inhibitor is a crystalline structure of ectodomain gp41 and from ectodomain partnered with peptide inhibitors (C34). The fusion inhibitor peptide was designed based on the discovery that two homologous domains in the gp41 virus protein must interact, one of these domains by heterologous proteins can bind and interfere with intramolecular interactions of viral proteins and have significant antiviral activity against HIV-1 (Lalezari et al., 2003; Wilen., et al 2012).

The $\mathrm{CCR}_{5}$ antagonist is a small molecule bonded to the hydrophobic pouch inside the $\mathrm{CCR}_{5}$ helical transmembrane that has been shown to inhibit viral replication in the macaque model and to prevent vaginal transmission. So far, three 
Indonesian Journal of Medicine (2017), 3(2): 184-191

https://doi.org/10.26911/theijmed.2017.02.03.06

antagonists (VCV, MVC, and Aplaviroc) have been shown to inhibit human replication virus. (Dorr et al., 2005; Veazey et al., 2005).

\section{Nutritional status}

According to WHO, nutritional support should be fundamental for a comprehensive response to HIV and AIDS. Malnutrition status in PLWHA were associated with chronic complication, increased morbidity, and reduced survival, even when ART is available (Who and Searo, 2008; Arjun et al., 2015).

A study in the United States found that micronutrient supplements significantly increased CD4 cell counts, and studies among HIV-infected adults in Haiti, Kenya, Malawi, and Zambia have shown significant positive effects of micronutrient supplementation. Increased intake of either macro or micronutrient food can optimize health outcomes for people living with HIV. (Kaiser et al., 2006).

A previous study from (Venter., et al 2009) showed the correlation between $\mathrm{CD} 4$ cell count, body weight, and body mass index (BMI). when $\mathrm{CD} 4$ number decrease by 100 cells / $\mu \mathrm{l}$ was associated with a $1.9 \mathrm{~kg}$ decrease in body weight of HIV-infected adults.

Diarrhea and fever were clinical complications associated with chronic malnutrition and weight loss. The impact of HIV/AIDS can decline dramatically if individuals take care of their health, plan for the future for their families and prevent further spread of infection Patients need to get educational nutrition on topics such as diet diversity, food safety principles and recommendations set for the community including food aid targeted.(Kirkcaldy et al., 2006; Hendricks et al., 2010).

Health workers should provide education and build nutrition support groups for PLWHA.

\section{Co-infection}

Co-infection is a major factor that promotes increased morbidity and mortality in PLWHA. The World Health Organization (WHO) reported that more or less a quarter of the 1.5 million deaths of HIV-infected patients were associated with tuberculosis and others co-infection (Lewandowski, 2015)

Based on the status of immune suppression in PLWHA, other co-infections can present with a variety of clinical syndromes with atypical manifestations that pose challenges in diagnosis and clinical management..

Chronic HIV co-infection is more than other infectious diseases, as the HIV virus immobilizes the immune system and allows reactivation of the active pathogens or increases susceptibility to exogenous pathogens. Although in the current era of morbidity and mortality the opportunistic diseases have declined, infections such as Cytomegalovirus (CMV), tuberculosis, hepatitis $\mathrm{C}$ and $\mathrm{B}$, Human Papillomavirus (HPV) remain a major health problem in chronically chronic HIV-infected individuals (Zanoni and Gandhi, 2014).

The role of co-infection in increasing morbidity and mortality remains a major problem today. In a study of HIV-infected populations in South Africa, showed that patients with active TB infection had elevated levels of soluble inflammatory biomarkers associated with monocyte activation, as well as T-cell activation surface markers (Sullivan et al., 2015)

Patients with active TB infection had lower CD4 T-cells. this explains that CoInfection plays a fundamental role in immune activation in all stages of coinfected HIV infection may increase the risk of higher cardiovascular disease (Boulougoura and Sereti, 2016). 


\section{REFERENCES}

Arjun BY, Unnikrishnan B, Ramapuram JT, Thapar R, Mithra P, Kumar N, Madi $\mathrm{D}$ et al. (2015) 'Factors Influencing Quality of Life among People Living with HIV in Coastal South India.', Journal of the International Association of Providers of AIDS Care.

Arts EJ, Hazuda DJ (2012). HIV-1 antiretroviral drug therapy', Cold Spring Harbor Perspectives in Medicine, 2(4).

Bacheler LT, Anton ED, Kudish P, Baker D, Bunville J, Krakowski K, Bolling L. et al. (2000) 'Human immunodeficiency virus type 1 mutations selected in patients failing efavirenz combination therapy', Antimicrobial Agents and Chemotherapy, 44(9): 2475-2484.

Boulougoura A, Sereti I (2016) 'HIV infection and immune activation: The role of coinfections', Current Opinion in HIV and AIDS, pp. 191-200.

Boyer PL, Sarafianos SG, Arnold E, Hughes $\mathrm{SH}$ (2001) 'Selective excision of AZTMP by drug-resistant human immunodeficiency virus reverse transcriptase.', Journal of virology, 75(10): 4832-42.

Dorr P, Westby M, Dobbs S, Griffin P, Irvine $\mathrm{B}$, Macartney $\mathrm{M}$, Mori $\mathrm{J}$. (2005) 'Maraviroc (UK-427,857), a potent, orally bioavailable, and selective small-molecule inhibitor of chemokine receptor $\mathrm{CCR} 5$ with broadspectrum anti-human immunodeficiency virus type 1 activity', Antimicrobial Agents and Chemotherapy, 49(11): 4721-4732.

Dykes C, Fox K, Lloyd A, Chiull Mi, Morse E, Demeter LM. (2001) 'Impact of clinical reverse transcriptase sequences on the replication capacity of HIV1 drug-resistant mutants', Virology, 285(2): 193-203.
Hasanah CI, Zaliha AR, Mahiran M. (2011) 'Factors influencing the quality of life in patients with HIV in Malaysia', Quality of Life Research, 20(1), pp. 91-100.

Hendricks KM, Erzen HD, Wanke CA, Tang AM. (2010) 'Nutrition Issues in the HIV-Infected Injection Drug User: Findings from the Nutrition for Healthy Living Cohort', Journal of the American College of Nutrition, 29(2), pp. 136-143.

Iacob SA, Iacob DG, and Jugulete G. (2017) 'Improving the adherence to antiretroviral therapy, a difficult but essential task for a successful HIV treatment-clinical points of view and practical considerations', Frontiers in Pharmacology.

KaiserJD, Campa AM, Ondercin JP, Leoung GS, Pless RF, Baum MK. (2006) 'Micronutrient supplementation increases CD4 count in HIV-infected individuals on highly active antiretroviral therapy: a prospective, double-blinded, placebo-controlled trial.', Journal of acquired immune deficiency syndromes (1999), 42(5): 523-528.

Kemenkes Republik Indonesia (2016). Situasi penyakit HIV AIDS di Indonesia, Pusat Data dan Informasi Kementerian Kesehatan RI.

Kementerian Kesehatan Republik Indonesia - Direktorat Jenderal Pengendalian Penyakit dan Penyehatan Lingkungan. (2011) Pedoman Nasional Tatalaksana Klinis Infeksi HIV dan Terapi Antiretroviral pada Orang Dewasa.

Kirkcaldy EM, Spiegel P, Abdalla F, Erdelmann F (2006) 'The development of programme strategies for integration of HIV, food and nutrition activities in refugee settings', UNAIDS 
Best Practice Collection.

Lalezari JP, Henry K, O'Hearn M, Montaner JSG, Piliero PJ, Trottier B, Walmsley S. et al. (2003) 'Enfuvirtide, an HIV-1 Fusion Inhibitor, for DrugResistant HIV Infection in North and South America', New England Journal of Medicine, 348(22): 2175-2185.

Lewandowski CM, Co-investigator N, Lewandowski CM (2015) WHO Glocal tuberculosis report 2015, The effects of brief mindfulness intervention on acute pain experience: An examination of individual difference.

Lodi S, Phillips A, Touloumi G, Geskus R, Meyer L, Thiébaut R, Pantazis N, et al. (2011) 'Time from human immunodeficiency virus seroconversion to reaching CD4+ cell count thresholds', Clinical infectious diseases: an official publication of the Infectious Diseases Society of America, 53(8): 817-25.

Naeger LK, Margot NA, Miller MD (2002) 'ATP-dependent removal of nucleoside reverse transcriptase inhibitors by human immunodeficiency virus type 1 reverse transcriptase', Antimicrobial Agents and Chemotherapy, 46(7): 2179-2184.

Oguntibeju OO. (2012) 'Quality of life of people living with HIV and AIDS and antiretroviral therapy.', HIV/AIDS (Auckland, N.Z.), 4: 117-24.

Paterson DL, Swindells S, Mohr J, Brester $\mathrm{M}$, Vergis EN, Squier C, Wagener MM. et al. (2000) 'Adherence to protease inhibitor therapy and outcomes in patients with HIV infection', Annals of internal medicine, 133(1): 21-30.

Rathbun C (2017) Antiretroviral Therapy for HIV Infection, Medscape.

Riourd ML, Ehresmann C, Parniak MA, Ehresmann B, Marquet R (2002) 'Primer unblocking and rescue of
DNA synthesis by azidothymidine (AZT)-resistant HIV-1 reverse transcriptase: Comparison between initiation and elongation of reverse transcription and between (-) and (+) strand DNA synthesis', Journal of Biological Chemistry, 277(21): 1861118618.

Schey KL, Luther JM, Rose KL (2016) 'HHS Public Access', 11(5): 1-21.

Shafer RW, Rhee SY, Pillay D, Miller V, Sandstrom P, Schapiro JM, Kuritzkes DR et al. (2007) 'HIV-1 protease and reverse transcriptase mutations for drug resistance surveillance.', AIDS (London, England), 21(2): 215-23.

Sluis-Cremer N, Temiz NA, Bahar I (2004) 'Conformational changes in HIV-1 reverse transcriptase induced by nonnucleoside reverse transcriptase inhibitor binding.', Current HIV research, 2(4): 323-32.

Sullivan ZA, Wong EB, Ndung'u T, Kasprowicz VO, Bishai WR. (2015) 'Latent and Active Tuberculosis Infection Increase Immune Activation in Individuals Co-Infected with HIV', EBioMedicine, 2(4): 334-340.

UNAIDS (2015) Global Aids Response Progress Reporting 2015, The Lancet.

Unit B, Africa S (2009). 'Nutritional status, quality of life and $\mathrm{CD} 4$ cell count of adults living with HIV/AIDS in the Ga-Rankuwa area (South Africa), 22(3): 124-129.

Veazey RS, Klasse PJ, Schader SM, Hu Q, Ketas TJ, Lu M, Marx PA. et al. (2005) 'Protection of macaques from vaginal SHIV challenge by vaginally delivered inhibitors of virus-cell fusion. Nature, 438(7064): 99-102.

Who and Searo (2008) 'Regional Consultation on Nutrition and HIV/A IDS: Evidence, lessons and recommendations for action in South-East Asia', 
in Regional Consultation on Nutrition and HIV/AIDS: Evidence, lessons and recommendations for action in SouthEast Asia , p. 63.

Wilen CB, Tilton JC, Doms RW (2012) 'Molecular mechanisms of HIV entry', Advances in Experimental Medicine and Biology, 726: 223-242.

Zanoni BC, Gandhi R T (2014) 'Update on opportunistic infections in the era of effective antiretroviral therapy', Infectious Disease Clinics of North America: 501-518. 